\title{
ISBAT NIKAH DALAM PERSPEKTIF KOMPILASI HUKUM ISLAM HUBUNGANNYA DENGAN KEWENANGAN PERADILAN AGAMA
}

\author{
Yusna Zaidah \\ Fakultas Syariah dan Ekonomi IAIN Antasari, Jl. Jenderal Ahmad Yani Km 4,5 Banjarmasin \\ e-mail: yusnazaidah@ymail.com
}

\begin{abstract}
Abstrak: Sebagai salah satu pelaksana kekuasaan kehakiman di Indonesia pengadilan di lingkungan Peradilan Agama diberi kewenangan mengadili perkara perdata Islam, salah satunya adalah di bidang perkawinan. Sebagai peradilan Islam, maka hukum materiil yang digunakan hukum Islam yang kemudian sering didefinisikan sebagai fikih, yang sudah barang tentu rentan perbedaan. Untuk menjembatani perbedaan dan untuk mewujudkan kepastian hukum, sekaligus untuk mewujudkan hukum Islam lahirlah Kompilasi Hukum Islam (KHI) yang tema utamanya positivisasi hukum Islam di Indonesia dan sebagai salah satu hukum terapan di lingkungan Peradilan Agama. Khusus mengenai perkara perkawinan adalah perkara pengesahan nikah yang dalam Kompilasi Hukum Islam dikualifikasikan sebagai upaya hukum yang disebut "isbat nikah". Dari beberapa landasan yuridis perkara isbat nikah sebagai kewenangan Peradilan Agama Kompilasi Hukum Islam adalah salah satu sumber hukum yang mengangkat lebih rinci mengenai alasan-alasan pengajuannya. Meskipun Kompilasi Hukum Islam tidak termasuk dalam hirarki Peraturan Perundang-undangan. Namun, demi untuk mengisi kekosongan hukum, maka pasal-pasal yang mengatur mengenai isbat nikah ini dinilai sebagai sebuah kebijakan yang sangat dibutuhkan oleh Peradilan Agama sebagai peradilan Islam di Indonesia.
\end{abstract}

\begin{abstract}
As one of the executors of judicial power in the courts in the Indonesian Religious Court is given the jurisdiction over civil causes of Islam, one of which is in the field of marriage. As an Islamic court, the substantive law that is used Islamic law, then it is often defined as fiqh, which are certainly vulnerable difference. To bridge differences and to create legal certainty, as well as to realize the Islamic law, then Compilation of Islamic Law (KHI) was born which positively main themes of Islamic law in Indonesia and as one of the law applied in the Religious Court. Especially with regard to matters of marriage is a matter of legalization of marriage in Islamic Law Compilation qualified as a remedy called "the isbat of marriage". Of a jurisdictional basis isbat marriage cases as authority Religious Court Compilation of Islamic Law is one of the sources of law which raised more detailed reasons filing. Although the Compilation of Islamic Law is not included in the hierarchy of legislation. However, in order to fill the legal vacuum, the provisions governing the confirmation of marriage is considered as a policy that is needed by the religious court as justice of Islam in Indonesia.
\end{abstract}

Kata kunci: Isbat nikah, kompilasi bukum islam, peradilan agama

\section{Pendahuluan}

Peradilan agama adalah salah satu pelaksana kekuasaan kehakiman di Indonesia yang memiliki otonomi penuh berdiri sendiri sejajar dan sederajat dengan lingkungan peradilan yang lain. Hal ini sebagaimana ditegaskan dalam UUD 1945 yang telah diamandemen, serta dalam Undang-undang pokok Kekuasaan kehakiman (UU.No.14 tahun 1970 Jo.UU.No 35 tahun 1999 yang telah direvisi oleh Undang-undang no.4 tahun 2004).

Sebagai salah satu peradilan khusus, peradilan agama diberi kewenangan mengadili perkara tertentu yakni perdata Islam dan bagi golongan rakyat tertentu, yakni masyarakat Muslim Indonesia. Hal ini sebagaimana diungkapkan dalam pasal 1 Undang-undang nomor 7 tahun 1989 tentang Peradilan Agama bahwa: Dalam Undang-undang ini yang dimaksud dengan: (1) Peradilan Agama adalah peradilan bagi orangorang yang beragama Islam. Mengenai kedudukan Peradilan Agama disebutkan dalam pasal (2) yang berbunyi: "Peradilan Agama adalah merupakan salah satu pelaksana kekuasaan kehakiman bagi rakyat pencari keadilan yang beragama Islam mengenai perkara perdata tertentu yang diatur dalam undang-undang". 
Dengan demikian, yang dimaksudkan dengan peradilan agama bukanlah sebagai tugas penyelesaian persengketaan atau perbedaan faham mengenai masalah agama. Walaupun dalam nama Peradilan Agama tidak mencantumkan kata-kata Islam, namun sudah jelas berdasarkan sejarah keberadaannya adalah merupakan peradilan yang diperuntukkan bagi orang-orang Islam mengenai perkara perdata yang dalam kehidupannya tidak dapat dipisahkan dari ketentuan hukum agamanya, yakni Islam.

Kekuasaan kehakiman di lingkungan badan Peradilan Agama dilaksanakan oleh Pengadilan Agama yang berada di tiap kotamadya atau ibukota kabupaten dan Pengadilan Tinggi Agama sebagai pengadilan banding yang berada di tiap ibukota propinsi. Adapun tugas pokok dari kedua lembaga ini adalah menerima, memeriksa dan mengadili serta menyelesaikan setiap perkara yang diajukan kepadanya. Kedua jenis pengadilan ini berpuncak kepada Mahkamah Agung sebagai pengadilan negara tertinggi. Hal ini sebagaimana bunyi pasal 3 dan 4 Undang-undang No.7 tahun 1989:

Pasal 3

1. Kekuasaan kehakiman di lingkungan Peradilan Agama dilaksanakan oleh;

a. Pengadilan Agama

b. Pengadilan Tinggi Agama

2. Kekuasaan kehakiman di lingkungan Peradilan Agama berpuncak pada Mahkamah Agung sebagai pengadilan negara tertinggi.

Pasal 4

1. Pengadilan Agama berkedudukan di kotamadya atau di ibukota kabupaten, dan daerah hukumnya meliputi wilayah kotamadya atau kabupaten.

2. Pengadilan Tinggi Agama berkedudukan di ibukota propinsi, dan daerah hukumnya meliputi wilayah propinsi.

Dalam pasal 49 Undang-undang No. 7 tahun 1989 tentang Peradilan Agama yang telah di amandemen dengan Undang undang Nomor 3 tahun 2006 yang berbunyi:

Pasal 49

"Pengadilan Agama bertugas dan berwenang memeriksa, memutus dan menyelesaikan perkara-perkara di tingkat pertama antara orangorang yang beragama Islam di bidang:
a. Perkawinan
b. Kewarisan
c. Wasiat
d. Hibah

e. Wakaf

f. Zakat

g. Infak

h. Sedekah; dan

i. Ekonomi Syari'ah.

Dari rumusan tertentu pasal 49 tersebut diketahui bahwa bidang perkara yang menjadi kekuasaan dan wewenang pengadilan di lingkungan Badan Peradilan Agama, terbagi dua, yakni:

- Bidang hukum keluarga

- Bidang hukum perikatan.

a. Bidang hukum keluarga

Untuk bidang hukum keluarga dapat dibagi menjadi dua yaitu bidang hukum perkawinan dan bidang hukum kewarisan. Bidang hukum perkawinan dimaksud sebagaimana isi pasal 49 ayat (2) yang berbunyi:

"Bidang perkawinan sebagaimana yang dimaksud dalam ayat (1) huruf a ialah halhal yang diatur dalam atau berdasarkan undang-undang mengenai perkawinan yang berlaku".

Sementara bidang hukum kewarisan dijelaskan dalam isi pasal 49 ayat (3) yang berbuyi: "Bidang kewarisan sebagaimana yang dimaksud dalam ayat (1) huruf b ialah penentuan siapa-siapa yang menjadi ahli waris penentuan mengenai harta peninggalan, penentuan bagian masing-masing ahli waris, dan melaksanakan pembagian harta peninggalan tersebut".

b. Bidang hukum perikatan

Bidang perikatan yang menjadi kekuasaan dan kewenangan pengadilan di lingkungan Badan Peradilan Agama sebagaimana yang diatur oleh pasal 49 ayat (1) Undang-undang Nomor 7 tahun 1989 adalah perkara-perkara wasiat, hibah, wakaf dan sedekah dan ekonomi syariah.

Pembidangan masalah wasiat, hibah, wakaf dan sedekah ini ke dalam hukum perikatan menurut Taufiq Hamami adalah karena hal-hal tersebut merupakan aqad tabarru, yakni transaksi pemindahan hak dari seseorang kepada orang atau pihak lain dengan tanpa imbalan apapun. ${ }^{1}$

Khusus mengenai perkara perkawinan dalam penjelasan pasal 49 huruf (a) disebutkan bahwa :"Yang dimaksud dengan "perkawinan" adalah hal-hal yang diatur dalam atau berdasarkan undang-undang mengenai perkawinan yang berlaku yang dilakukan menurut syariah, antara

1 Taufiq Hamami, Mengenal Lebih Dekat, Kedudukan dan Eksistensi Peradilan Agama dalam Sistem Tata Hukum di Indonesia, (Bandung: Alumni, tt). hlm. 113. 
lain pada angka (22) disebutkan perkara "pernyatan tentang sahnya perkawinan yang terjadi sebelum Undang Undang Nomor 1 tahun 1974 tentang perkawinan yang dijalankan menurut peraturan yang lain." Untuk selanjutnya, perkara ini disebut sebagai perkara pengesahan nikah yang dalam Kompilasi Hukum Islam dikualifikasikan sebagai upaya hukum yang disebut isbat nikah. ${ }^{2}$

\section{Kompilasi Hukum Islam sebagai Sumber Hukum}

Sebagai pelaksana keluasaan kehakiman Peradilan Agama dipegang oleh Pengadilan Agama untuk tingkat pertama dan Pengadilan Tinggi Agama untuk tingkat banding, yang masing-masing mempunyai wewenang 3 yang diatur oleh undang-undang. Wewenang tersebut antara lain meliputi kewenangan terhadap jenis perkara yang disebutkan dalam pasal 49 Undang Undang No. 7 tahun 1989 Jo. Undang Undang No. 3 tahun 2006 tentang Peradilan Agama.

Dalam menjalankan fungsinya, Peradilan Agama berpegang kepada beberapa sumber hukum, baik formal maupun materiil. Untuk hukum materiil dalam lingkungan Peradilan Agama yang juga merupakan Peradilan Islam selama ini berpegang kepada beberapa peraturan perundang-undangan yakni antara lain; Undang undang No. 1 tahun 1974 tentang Perkawinan, Undang Undang No. 7 tahun 1989 jo. UndangUndang No. 3 tahun 2006 tentang Peradilan Agama, Undang Undang No. 41 tahun 2004 tentang Wakaf.

Secara historis Peradilan Agama sebagai peradilan Islam hukum materiilnya adalah hukum Islam yang kemudian sering didefinisikan sebagai fikih, yang sudah barang tentu rentan dengan perbedaan. Untuk menjembatani perbedaan dan mewujudkan kepastian hukum, sekaligus untuk mewujudkan hukum Islam, setidaknya di bidangbidang hukum perkawinan, waris dan wakaf menjadi hukum tertulis, maka Menteri Agama pada tanggal 14 Maret 1988 mengajukan naskah Kompilasi Hukum Islam kepada Presiden yang akhirnya pada tanggal 19 Juni 1991 lahirlah

2 M. Yahya Harahap, Kedudukan Kewenangan dan Acara Peradilan Agama, (Jakarta: Sinar Grafika, 2001), hlm. 145.

3 Kata Wewenang atau kekuasaan pada umumnya dimaksudkan adalah kekuasaan absolut. Dalam berbagai peraturan perundang-undangan kekuasaan absolut sering disingkat dengan kata kekuasaan saja,. Ibid., hlm. 140.
Instruksi Presiden No. 1 tahun 1991 tentang Penyebaran Kompilasi Hukum Islam. ${ }^{4}$

Tema utama KHI adalah mempositifkan hukum Islam di Indonesia. Dengan mempositifkan hukum Islam secara terumus dan sistematik dalam kitab hukum dapat beberapa sasaran pokok yang hendak dituju antara lain yakni ${ }^{5}$ :

a. Untuk melengkapi pilar Peradilan Agama.

Ada tiga pilar sokoguru kekuasaan kehakiman dalam melaksanakan fungsi peradilan yang diamanatkan pasal 24 Undang-undang Dasar 1945 jo. pasal 10 Undang-undang Nomor 14 Tahun 1970. Pertama, adanya badan peradilan yang teroganisir berdasarkan kekuatan Undangundang. Secara konstitusional dan teoritis pilar ini telah terpenuhi. Kedua, adanya organ pelaksana. Hal ini sudah sejak lama dimiliki oleh lingkungan Peradilan Agama, sesuai dengan pasang surut yang dialaminya dalam perjalanan sejarah. Ketiga, adanya sarana hukum sebagai rujukan. Sebenarnya, sebagian hukum materiil yang menjadi yurisdiksi Peradilan Agama telah dikodifikasi dalam Undang-undang Nomor 1 Tahun 1974 dan Peraturan Pemerintah Nomor 9 Tahun 1975. Akan tetapi, pada dasarnya halhal yang ada di dalamnya baru merupakan pokok-pokok, belum secara menyeluruh terjabarkan ketentuan-ketentuan hukum perkawinan yang diatur dalam Islam. Akibatnya, para hakim merujuk pada doktrin fikih. Terjadilah suasana praktik Peradilan Agama yang menonjolkan dan "mempertarungkan" kitab fikih dan pendapat mazhab.

b. Menyamakan persepsi penerapan hukum Islam.

Dengan adanya KHI sebagai kitab hukum, para hakim tidak dibenarkan menjatuhkan putusan-putusan yang berdisparitas. Dengan memedomani KHI para hakim diharapkan dapat menegakkan hukum dan kepastian hukum yang seragam tanpa mngurangi kemungkinan terjadinya putusan-putusan yang bercorak variabel, asal tetap proporsional secara kasuistik. Demikian

4 A. Basiq Djalil, Peradilan Agama di Indonesia, (Jakarta: Kencana, 2006), hlm. 149.

5 http://abdabina.staff.umm.ac.id/archives/240 dalam tulisan Ahdabi, "Kompilasi Hukum Islam", h. 1, Diakses 2/7/2013. 
pula halnya bagi pencari keadilan. Mereka tidak dapat lagi mengajukan dalih dan dalil ikhtilaff. Mereka tidak dapat lagi memaksakan kehendaknya agar hakim mengadilinya menurut pendapat dan doktrin mazhab tertentu.

Hal yang sama, juga berlaku bagi penasihat hukum. Ia hanya diperkenankan mengajukan tafsir bertitiktolak dari rumusan kitab hukum KHI. Sehingga semua pihak yang terlibat sama-sama mencari sumber dari muara yang sama, yaitu Kitab Kompilasi Hukum Islam.

c. Mempercepat proses taqrîb bayn al-ummah.

KHI dapat diharapkan sebagai jembatan penyeberangan ke arah memperkecil pertentangan dan perbantahan kbilâfiyah. Memang hal ini bukan berarti lenyapnya seluruh permasalahan ikbtilâf. Akan tetapi, misi taqrîb bayn al-ummah yang dicontohkan KHI sedikit banyak akan memperngaruhi arus transformasi taqrîb terhadap bidangbidang hukum yang lain.

d. Menyingkirkan paham private affairs

Dari pengamatan dan pengalaman yang dapat diraba, dalam penghayatan kesadaran masyarakat Islam selam ini, nilai-nilai hukum Islam selalu dianggap sebagai urusan pribadi; urusan hubungan vertikal seseorang dengan Tuhan. Hendak menalak istri atau berpoligami adalah urusan pribadi. Orang lain dan penguasa tidak boleh campur tangan. Tidak perlu penertiban, persyarakatan tambahan, maupun tindakan administratif. Paham yang bercorak private affairs ini bukan hanya terdapat di kalangan masyarakat awam, tetapi meliputi kalangan elite lingkungan ulama dan fuqabâ. Kelahiran KHI sebagai hukum positif dan unifikatif menyingkirkan praktik private affairs. Dengan lahirnya KHI, hukum Islam yang terkandung di dalamnya sudah menjadi kereta api yang akan melindas setiap penyeberang yang tidak mematuhinya.

Menurut Wahyu Widiana ${ }^{6}$, Kompilasi Hukum Islam sebagai hukum terapan di lingkungan Peradilan Agama dapat dikategorikan sebagai hukum tertulis karena sebagian materi yang terkandung di dalamnya adalah kutipan atau merujuk kepada peraturan perundangan yang berlaku seperti Undang undang Nomor 1 tahun 1974 tentang Perkawinan dan sebagainya.
Sebagaimana diketahui bahwa sistem hukum Nasional mencakup berbagai unsur. Pertama, landasan ideal dan konstitusional, yaitu Pancasila dan Undang-undang Dasar 1945. Kedua, tata urut peraturan perundang-undangan yang menjadi sumber hukum tertulis dalam penerapan dan pengembangan hukum. Ketiga, tatanan hukum masyarakat, bersifat majemuk, terutama hukum tidak tertulis. Keempat, pranata peradilan sebagai pelaksana dalam penegakan hukum dan keadilan?

Termasuk dalam tatanan hukum itu adalah tatanan hukum Islam yang termuat dalam kitab suci al-Qur'an, kitab-kitab Hadis, dan berbagai pandangan fuqahâ yang ditulis dalam berbagai kitab fikih. Tatanan hukum Islam itu berkedudukan sebagai salah satu bahan hukum Nasional, khususnya hukum tertulis. Oleh karena tatanan hukum itu bersifat majemuk, tentu saja terjadi interaksi antar tatanan hukum dalam proses pembentukan dan pengembangan sistem hukum nasional. Termasuk dalam penyusunan dan perumusan Kompilasi Hukum Islam itu terjadi interaksi antara tatanan hukum.

Dengan demikian, kedudukan KHI dalam sistem hukum nasional, diukur oleh unsur-unsur sistem hukum nasional sebagaimana dikemukakan. Pertama, landasan ideal dan konstitusional KHI adalah Pancasila dan Undang-undang kedudukan KHI dalam sistem hukum Nasional, diukur oleh unsur-unsur sistem hukum Nasional sebagaimana dikemukakan Undang-undang Dasar 1945. Hal itu dimuat dalam konsideran Instruksi Presiden dan dalam Penjelasan Umum KHI. Ia disusun sebagai bagian dari sistem hukum Nasional yang menjamin kelangsungan hidup beragama berdasarkan Ketuhanan Yang Maha Esa yang sekaligus merupakan perwujudan kesadaran hukum masyarakat dan bangsa Indonesia. Kedua, ia dilegalisasi oleh instrumen hukum dalam bentuk Instruksi Presiden yang dilaksanakan oleh Keputusan Menteri Agama, yang merupakan bagian dari rangkaian peraturan perundangundangan yang berlaku. Ketiga, ia dirumuskan dari tatanan hukum Islam yang bersumber dari al-Qur'an dan Sunnah Rasul. Hal itu yang menjadi inti hukum Islam, yang mencakup berbagai dimensi. Ia merupakan perwujudan hukum Islam yang bercorak keindonesiaan. Keempat, saluran dalam aktualisasi KHI antara lain pengadilan dalam lingkungan Peradilan

7 Ibid. 
Agama, sebagaimana dapat ditafsirkan dari Penjelasan Umum KHI. KHI yang tertuang dalam Instruksi Presiden Nomor 1 Tahun 1991, dilaksanakan dengan Keputusan Menteri Agama Nomor 154 Tahun 1991. Penyusunan KHI mengenai perkawinan didasarkan pada Undangundang Nomor 22 Tahun 1946 jo. Undangundang Nomor 32 Tahun 1954 dan Undangundang Nomor 1 Tahun 1974 jo. Peraturan Pemerintah Nomor 9 Tahun 1975.

Hal itu menunjukkan bahwa KHI merupakan hukum positif Islam untuk melaksanakan peraturan perundang-undangan yang berlaku. Ia memiliki konsistensi dengan peraturan perundang-undangan yang kedudukannya lebih tinggi.

\section{Proses Isbat Nikah di Peradilan Agama}

Isbat nikah berasal dari bahasa Arab yang terdiri dari itsbat dan nikah. Menurut bahasa itsbat berarti "penetapan, pengukuhan dan pengiyaan"8, Itsbat nikah dalam bahasa Indonesia dikenal dengan sebutan isbat nikab yang diartikan dengan pengukuhan dan penetapan perkawinan melalui pencatatan dalam upaya mendapatkan pengesahan suatu perkawinan menurut hukum yang berlaku. Dalam Keputusan Mahkamah Agung RI Nomor KMA/032/SK/2006 tentang Pedoman Pelaksanaan Tugas dan Administrasi Pengadilan disebutkan bahwa :'Itsbat nikah adalah pengesahan atas perkawinan yang telah dilangsungkan menurut syariat agama Islam, akan tetapi tidak dicatat oleh KUA atau PPN yang berwenang.

Itsbat nikah di Pengadilan Agama oleh para pemohon digunakan sebagai alas hukum untuk mencatatkan perkawinannya pada Pegawai Pencatat Nikah KUA Kecamatan, dan dari Kecamatan akan mengeluarkan Buku Kutipan Akta Nikah sebagai bukti otentik bahwa suatu perkawinan telah tercatat, untuk selanjutnya Buku Kutipan Akta Nikah itu akan digunakan oleh yang bersangkutan untuk mengurus Akta Kelahiran Anak pada Kantor Catatan Sipil yang mewilayahinya dengan dilampiri penetapan itsbat nikah oleh Pengadilan Agama.

Pengadilan Agama dengan itsbat nikah mempunyai andil dan kontribusi yang sangat besar dan penting dalam upaya memberikan rasa keadilan dan kepastian serta perlindungan hukum

8 Ahmad Warson Munawwir, Kamus Al-Munawwir, Arab-Indonesia, (Yogyakarta, tp. 1984), hlm. 157. bagi masyarakat. Mereka yang selama ini tidak memiliki Kartu Keluarga karena tidak mempunyai Buku Nikah, setelah adanya penetapan itsbat nikah oleh Pengadilan Agama mereka akan mudah mengurus Kartu Keluarga dan Akta Kelahiran anak-anak mereka sehingga sudah tidak kesulitan untuk masuk sekolah. Bahkan, calon jamaah haji yang tidak mempunyai Buku Nikah sangat terbantu dengan itsbat nikah oleh Pengadilan Agama untuk mengurus paspor.

Itsbat nikah merupakan penetapan pengadilan tentang sahnya suatu perkawinan. Pasal 2 Ayat 1 Undang-Undang Nomor 1 Tahun 1974 Tentang Perkawinan menyebutkan bahwa perkawinan adalah sah, apabila dilakukan menurut hukum masing-masing agamanya dan kepercayaannya itu. Dalam penjelasan Pasal 2 disebutkan bahwa Dengan perumusan pada Pasal 2 ayat (1) ini, tidak ada Perkawinan diluar hukum masingmasing agamanya dan kepercayaannya itu, sesuai dengan Undang-undang Dasar 1945. Yang dimaksud dengan hukum masing-masing agamanya dan kepercayaannya itu termasuk ketentuan perundang-undangan yang berlaku bagi golongan agamanya dan kepercayaannya itu sepanjang tidak bertentangan atau tidak ditentukan lain dalam Undang-undang ini. Berdasarkan ketentuan Pasal 2 Ayat 1 UUP dan penjelasannya ini, dapat diketahui bahwa patokan untuk mengetahui suatu perkawinan sah adalah hukum masing-masing agama dan kepercayaan para pihak serta ketentuan perundang-undangan yang berlaku sepanjang tidak bertentangan atau tidak ditentukan lain dalam Undang Undang Perkawinan.

Ketentuan pencatatan perkawinan diatur dalam Pasal 2 Ayat (2) Undang-Undang Nomor 1 Tahun 1974 tentang Perkawinan bertujuan agar terjamin ketertiban perkawinan bagi masyarakat Islam (Pasal 5 Ayat (2) Kompilasi Hukum Islam) dan untuk menjamin ketertiban hukum (legal order) sebagai instrumen kepastian hukum, kemudahan hukum, di samping sebagai bukti otentik adanya perkawinan. Pencatatan perkawinan merupakan salah satu bentuk intervensi pemerintah atau negara untuk melindungi dan menjamin terpenuhinya hak-hak sosial setiap warga negara, khususnya pasangan suami istri, serta anak-anak yang lahir dari perkawinan itu.

Pasal 2 ayat (2) menyebutkan bahwa tiap-tiap perkawinan dicatat menurut peraturan perundang-undangan yang berlaku. Pencatatan perkawinan akan menimbulkan kemaslahatan umum karena dengan pencatatan ini akan memberikan 
kepastian hukum terkait dengan hak-hak suami/isteri, kemaslahatan anak maupun efek lain dari perkawinan itu sendiri. Perkawinan yang dilakukan di bawah pengawasan atau di hadapan Pegawai Pencatat Nikah/Kantor Urusan Agama akan mendapatkan Akta Nikah sebagai bukti telah dilangsungkannya sebuah perkawinan.

Akta Nikah merupakan akta autentik juga berfungsi untuk memperoleh kepastian hukum sebuah perkawinan. Kepastian hukum sendiri disebut juga dengan istilah principle of legal security dan rechtszekerbeid. Kepastian hukum adalah perangkat hukum suatu negara yang mampu menjamin hak dan kewajiban setiap warga negara. Kepastian hukum (rechtszekerheid) juga diartikan dengan jaminan bagi anggota masyarakat, bahwa semuanya akan diperlakukan oleh negara/penguasa berdasarkan peraturan hukum, tidak dengan sewenang-wenang. Karena Akta Nikah tersebut dibuat oleh dan di hadapan Pegawai Pencatat Nikah sebagai pejabat yang berwenang untuk melakukan pencatatan perkawinan, dibuat sesuai dengan bentuk yang ditetapkan oleh Peraturan Pemerintah Nomor 9 Tahun 1975 dan dibuat di tempat Pegawai Pencatat Nikah/Kantor Urusan Agama tersebut melaksanakan tugasnya.

Meskipun, Peraturan Perundang-Undangan sudah mengharuskan adanya Akta Nikah sebagai bukti perkawinan, namun tidak jarang terjadi suami istri yang telah menikah tidak mempunyai Kutipan Akta Nikah. Kemungkinan yang jadi penyebab tidak adanya Kutipan Akta Nikah disebabkan oleh beberapa faktor seperti;

a. Kelalaian pihak suami isteri atau pihak keluarga yang melangsungkan pernikahan tanpa melalui prosedur yang telah ditentukan pemerintah. Hal ini kelihatan semata-mata karena ketidaktahuan mereka mereka terhadap peraturan dan ketentuan yang ada (buta hukum);

b. Besarnya biaya yang dibutuhkan bila mengikuti prosedur resmi tersebut;

c. Karena kelalaian petugas Pegawai Pecatat Nikah/wakil seperti dalam memeriksa suratsurat/persyaratan-persyaratan nikah atau berkas-berkas yang ada hilang;

d. Pernikahan yang dilakukan sebelum lahirnya Undang-Undang Perkawinan

e. Tidak terpenuhinya syarat-syarat untuk berpoligami terutama tidak adanya persetujuan dari isteri sebelumnya.

Kompilasi Hukum Islam kemudian mempertegas lagi dalam pasal 7 ayat (2) yang menyebutkan bahwa:" Dalam hal perkawinan tidak dapat dibuktikan dengan akte nikah, dapat diajukan itsbat nikahnya ke Pengadilan Agama." Ketentuan ini lebih mempertegas kewenangan peradilan agama terhadap kasus pembuktian perkawinan yang tidak memiliki akte nikah dengan menempuh prosedur pengesahan di pengadilan. Dalam Kompilasi Hukum Islam ini upaya hukum itsbat nikah tidak hanya meliputi pengabsahan perkawinan yang terjadi sebelum UU. No. 1 tahun 1974 berlaku, tapi juga menunjukkan ke arah pembuktian dan sekaligus pengabsahan nikah. ${ }^{9}$ Kemudian dalam Undangundang nomor 7 tahun 1989 tentang Peradilan Agama pada pasal 49 ayat (2) menyebutkan bahwa: "Bidang perkawinan sebagaimana yang dimaksud dalam ayat (1) huruf a ialah hal-hal yang diatur dalam atau berdasarkan undangundang mengenai perkawinan yang berlaku", sedang dalam penjelasan pasal 49 ayat 2 tersebut dikatakan bahwa "salah satu bidang perkawinan yang di atur dalam undang- undang Nomor 1 tahun 1974 adalah: "Pernyataan tentang sahnya perkawinan yang terjadi sebelum Undang undang nomor 1 tahun 1974 tentang Perkawinan dijalankan menurut peraturan yang lain".

Dari beberapa landasan yuridis itsbat nikah sebagai kewenangan Peradilan Agama di atas, hanya Kompilasi Hukum Islam yang menjelaskan lebih rinci mengenai itsbat nikah termasuk alasan pengajuannya. Alasan pengajuan itsbat nikah dimaksud disebutkan dalam Kompilasi Hukum Islam pasal 7 ayat (3) disebutkan bahwa :" Itsbat nikah yang dapat diajukan ke Pengadilan Agama terbatas mengenai hal-hal yang berkenaan dengan:

a. Adanya perkawinan dalam rangka penyelesaian perceraian;

b. Hilangnya akte nikah;

c. Adanya keraguan tentang sah atau tidaknya salah satu syarat perkawinan;

d. Adanya pekawinan yang terjadi sebelum berlakunya Undang undang no. 1 tahun 1974 tentang perkawinan; dan

e. Perkawinan yang dilakukan oleh mereka yang tidak mempunyai halangan perkawinan menurut Undang undang no. 1 tahun 1974.

Mengenai alasan pengajuan itsbat nikah karena adanya perkawinan dalam rangka penyelesaian perceraian maksudnya adalah terjadinya pengajuan perceraian dari salah satu pihak baik suami

9 Ibid. 
ataupun isteri ke Pengadilan Agama sementara status perkawinannya tidak dapat dibuktikan dengan akte nikah karena perkawinan di lakukan di bawah tangan. Oleh karena salah satu syarat pengajuan perkara cerai adalah melampirkan copy akte nikah yang dibuat oleh Pegawai Pencatat Nikah. Maka, bagi mereka yang perkawinannya di bawah tangan otomatis harus menempuh upaya hukum itsbat nikah terlebih dahulu sebelum menyelesaikan perkara perceraiannya di Pengadilan Agama.

Di samping itu, itsbat nikah juga dapat dilakukan bagi mereka yang kehilangan akte nikah. Hal ini dilakukan untuk menggantikan akte nikah yang dikeluarkan PPN. Karena pada dasarnya akte nikah adalah sebagai bukti autentik menunjukkan telah terjadi perkawinan yang sah secara hukum.

Dalam Peraturan Pemerintah Nomor 9 tahun 1975 sebagai perangkat organik Undang Undang Nomor 1 tahun 1974 secara imperatif pada pasal 10 ayat (3) menekankan keterlibatan PPN dalam suatu perkawinan. Keterlibatan pencatat dalam suatu perkawinan kapasitasnya sebagai pegawai atau pejabat yang diangkat pemerintah dengan tugas untuk mengawasi terjadinya perkawinan dan mencatatnya Menurut Undang Undang Nomor 1 tahun 1974, setidaknya ada dua fungsi dari pencatatan perkawinan; pertama untuk tegaknya hukum perkawinan. Dengan demikian akan diketahui apakah perkawinan yang akan dilangsungkan tersebut sesuai dengan ketentuan atau sebaliknya. Kedua, untuk tertib administrasi, jika perkawinan akan dilangsungkan tersebut sesuai dengan ketentuan atau dengan hukum yang berlaku maka pegawai pencatat akan mencatatnya sebagai bukti autentik telah terjadi perkawinan menurut hukum yang berlaku. Sebaliknya, jika perkawinan yang hendak dilangsungkan tersebut tidak sesuai dengan hukum yang berlaku, maka pegawai pencatat tidak akan mencatatnya. ${ }^{10}$

Dengan demikian, diketahui bahwa antara aspek tegaknya hukum dengan tertib administrasi dalam suatu perkawinan merupakan hal yang tidak dapat dipisah-pisahkan. Dengan kata lain, pencatatan suatu perkawinan menjadi sangat penting karena berhubungan langsung dengan sah atau tidaknya suatu perkawinan.

Di samping itu, itsbat nikah juga dapat diajukan jika adanya keraguan tentang sah atau

10 Lihat pasal 2 ayat 1 dan 2 Undang Undang Nomor 1 tahun 1974. tidaknya salah satu syarat perkawinan. Karena pada dasarnya syarat perkawinan itu adalah merupakan syarat komulatif, yang berarti bahwa jika tidak terpenuhi salah satu syarat perkawinan tersebut, maka perkawinan dinyatakan tidak sah. Dengan demikian, ini membuka peluang untuk menguji sahnya suatu perkawinan jika terjadi keraguan pada salah satu syaratnya.

Adapun pihak-pihak yang berhak (peson standi in yudicio) mengajukan permohonan itsbat nikah menurut pasal 7 ayat (4) KHI adalah ; suami atau isteri, anak anak mereka, wali nikah dan pihak yang berkepentingan dengan perkawinan itu.

Dari ketentuan itu tergambar bahwa pihak yang berhak mengajukan itsbat nikah adalah pihak yang terlibat langsung dalam perkawinan sebagaimana yang diatur oleh peraturan perundang-undangan. Pihak yang dimaksud adalah suami, istri dan wali nikah. Di samping itu, ada pihak lain yang dimungkinkan terlibat dan berkepentingan dengan perkawinan tersebut, seperti orang tertentu yang mempunyai hubungan darah dengan yang diisbatkan nikahnya seperti anak, saudara dan lain-lain atau pejabat tertentu karena jabatannya seperti PPN. ${ }^{11}$

Dalam prakteknya, itsbat nikah ini dapat dikelompokkan dalam perkara yang tidak mengandung unsur sengketa (yurisdiksi volunter), yang mana hanya ada satu pihak yang berkepentingan dalam perkara itu (oneigenlyke rechtspraak.). ${ }^{12}$

Adapun perkara voluntair memiliki ciri-ciri sebagai berikut: Pertama, masalah yang diajukan bersifat sepihak semata (for the benefit of one party only). Maksudnya adalah benar-benar murni untuk meyelesaikan kepentingan Pemohon tentang permasalahan perdata yang memerlukan kepastian hukum. Dengan demikian pada prinsipnya, apa yang dipermasalahkan, tidak bersentuhan dengan hak dan kepentingan pihak lain. Kedua, permasalahan yang dimohon penyelesaiannya, pada prinsipnya tanpa sengket dengan pihak lain (without dispute of differences with another party). Berdasarkan ukuran ini, tidak dibenarkan mengajukan permohonan tentang penyelesaian sengketa hak atau kepemilikan maupun penyerahan serta pembayaran sesuatu oleh orang lain atau pihak ketiga. Ketiga, tidak ada orang lain atau pihak ketiga yang ditarik sebagai

11 Enas Nasruddin, op. Cit., hlm. 91.

12 Enas Nasruddin, "Ikhwal Isbat Nikah", Artikel dalam Mimbar bukum. No. 33 tahun, (Jakarta: Al Hikmah dan Ditbinbapera,1977), hlm. 87. 
lawan, tetapi bersifat experte. Hal ini berarti perkara benar-benar murni dan mutlak satu pihak atau bersifat ex-perte. Pemohonan untuk kepentingan sepihak atau yang terlibat dalam permasalahan hukum yang diajukan dalam kasus itu hanya satu pihak. ${ }^{13}$

Jadi itsbat nikah ini bersifat volunteir (perkara yang pihaknya hanya terdiri dari pemohon saja, tidak ada pihak termohon):

a. Jika permohonan diajukan oleh suami dan isteri secara bersama-sama;

b. Jika permohonan diajukan oleh suami/isteri yang ditinggal mati oleh suami/isterinya, sedang Pemohon tidak mengetahui ada ahli waris lainnya selain dia.

Namun perkara itsbat nikah dapat bersifat kontensius, (perkara yang pihaknya terdiri dari pemohon melawan termohon atau penggugat melawan tergugat):

a. Jika permohonan diajukan oleh salah seorang suami atau isteri, dengan mendudukkan suami atau isteri sebagai pihak Termohon;

b. Jika pernohonan diajukan oleh suami atau isteri sedang salah satu dari suami isteri tersebut masih ada hubungan perkawinan dengan pihak lain, maka pihak lain tersebut juga harus dijadikan pihak dalam permohonan tersebut;

c. Jika permohonan diajukan oleh suami atau isteri yang ditinggal mati oleh suami atau isterinya, tetapi dia tahu ada ahli waris lainnya selain dia;

d. Jika permohonan diajukan oleh wali nikah, ahli waris atau pihak lain yang berkepentingan.

Adapun upaya hukum yang dapat dilakukan terhadap hasil akhir persidangan pengadilan dalam perkara itsbat nikah ini adalah:

1. Atas penetapan itsbat nikah yang bersifat voluntair, apabila permohonannya ditolak oleh pengadilan, Pemohon dapat menempuh upaya hukum kasasi;

2. Atas putusan itsbat nikah yang bersifat kontensius, dapat ditempuh upaya banding, kasasi dan PK;

3. Orang lain yang berkepentingan, jika orang lain tersebut sebagai suami/isteri atau ahli waris, sedang ia tidak menjadi pihak dalam permohonan itsbat nikah, dapat mengajukan perlawanan kepada pengadilan yang

13 M. Yahya Harahap, Hukum Acara Perdata, (tt: tp, tth.), hlm. 29. memeriksa perkara itsbat nikah tersebut, selama perkara belum diputus;

4. Orang lain yang berkepentingan, jika orang lain tersebut sebagai suami/isteri atau perempuan lain yang terikat perkawinan sah atau wali nikah atau anak, dapat mengajukan intervensi kepada Pengadilan Agama yang memeriksa perkara tersebut selama perkara belum diputus;

5. Pihak lain yang berkepentingan, jika pihak lain tersebut adalah orang-orang yang tersebut pada angka 4 di atas, dapat mengajukan gugatan pembatalan pekawinan yang telah diitsbatkan oleh Pengadilan Agama ${ }^{14}$.

Landasan yuridis yang digunakan untuk kewenangan peradilan dalam penyelesaian itsbat nikah ini secara historis dapat dilihat dalam himpunan penetapan dan putusan Pengadilan Agama di tahun 1950-an yang menggunakan dasar hukum Staatsblad tahun 1882 Nomor 152 dan Staatsblad tahun 1937 nomor 116 dan 610 untuk Jawa dan Madura, Staatsblad tahun 1937 nomor 638 dan 639 untuk sebagian Kalimantan Selatan dan Timur, serta Peraturan Pemerintah Nomor 45 tahun 1957 untuk luar Jawa dan Madura serta sebagian Kalimantan Selatan dan Kalimantan Timur. ${ }^{15}$

Hal di atas membuktikan bahwa praktek pengesahan nikah atau itsbat nikah dalam masyarakat Islam di Indonesia sebenarnya sudah ada sejak dulu, sehingga perlu pengaturan yang lebih rinci sambil disesuaikan dengan kondisi terkini. Itsbat nikah yang dilaksanakan oleh Pengadilan Agama karena pertimbangan maslahat bagi umat Islam. Itsbat nikah sangat bermanfaat bagi umat Islam untuk mengurus dan mendapatkan hak-haknya yang berupa surat-surat atau dokumen pribadi yang dibutuhkan dari instansi yang berwenang serta memberikan jaminan perlindungan kepastian hukum terhadap masing-masing pasangan suami istri.

Selanjutnya, dalam pasal 64 UU. No. 1 tahun 1974 disebutkan bahwa: "Untuk perkawinan dan

14 Masrum M Noor, "Isbat Nikah Bagi Warga Negara Indonesia di Luar Negeri”, http:/ / www.pa-magelang.go.id.l Diakses tanggal 12/5/2013

15 Damsyi Hasan, Permasalah Isbat Nikah (Kajian terbadap pasal 2 UU. No. 1 tabun 1974 dan pasal 7 KHI) Artikel dalam Mimbar Hukum, No. 31 (Jakarta: Al-Hikmah dan Ditbinbapera Islam, 1997), hlm. 76. 
segala sesuatu yang berhubungan dengan perkawinan yang terjadi sebelum UU ini berlaku yang dijalankan menurut peraturan-peraturan lama adalah sah". Pernyataan ini sebagai pengesahan bentuk bentuk praktek yang berhungan dengan perkawinan, tentunya termasuk juga di dalamnya adalah praktek pengesahan nikah atau itsbat nikah ini.

Dewasa ini, permohonan itsbat nikah yang diajukan ke Pengadilan Agama dengan berbagai alasan, pada umumnya perkawinan yang dilaksanakan pasca berlakunya Undang-Undang Nomor 1 Tahun 1974 tentang Perkawinan. Pengadilan Agama selama ini menerima, memeriksa dan memberikan penetapan permohonan itsbat nikah terhadap perkawinan yang dilangsungkan setelah berlakunya UndangUndang Nomor 1 Tahun 1974 (kecuali untuk kepentingan mengurus perceraian, karena akta nikah hilang, dan sebagainya), menyimpang dari ketentuan perundang-undangan (Pasal 49 Ayat (2) Undang-Undang Nomor 7 Tahun 1989 yang telah diubah dengan Undang-Undang Nomor 3 Tahun 2006 terakhir diubah dengan UndangUndang Nomor 50 Tahun 2009 tentang Peradilan Agama dan penjelasannya).

Namun, itsbat nikah sangat dibutuhkan oleh masyarakat, maka hakim Pengadilan Agama melakukan "ijtihad" dengan menyimpangi tersebut, kemudian mengabulkan permohonan itsbat nikah berdasarkan ketentuan Pasal 7 Ayat (3) huruf e Kompilasi Hukum Islam. Apabila perkawinan yang dimohonkan untuk diitsbatkan itu tidak ada halangan perkawinan sebagaimana diatur di dalam Undang-Undang Nomor 1 Tahun 1974 tentang Perkawinan, maka Pengadilan Agama akan mengabulkan permohonan itsbat nikah meskipun perkawinan itu dilaksanakan pasca berlakunya Undang-Undang No. 1 Tahun 1974 tentang Perkawinan. Padahal, Kompilasi Hukum Islam (KHI) tidak termasuk dalam hierarki Peraturan Perundang-Undangan yang disebutkan dalam Pasal 7 Undang-Undang Nomor 10 Tahun 2004 tentang Pembentukan Peraturan Perundang-undangan. Oleh karena itu, penetapan itsbat nikah oleh Pengadilan Agama tersebut, tidak lebih hanya sebagai kebijakan untuk mengisi kekosongan hukum yang mengatur tentang itsbat nikah terhadap perkawinan yang dilaksanakan pasca berlakunya Undang-Undang Nomor 1 Tahun 1974 tentang Perkawinan.

\section{Penutup}

Dari uraian sebelumnya dapat disimpulkan bahwa: Pertama, Peradilan Agama adalah peradilan Islam di Indonesia, sebab dari jenis-jenis perkara yang menjadi kewenangannya seluruhnya adalah jenis perkara yang didasarkan kepada agama Islam salah satunya adalah perkara pengesahan nikah yang dalam Kompilasi Hukum Islam dikualifikasikan sebagai upaya hukum yang disebut itsbat nikah.

Kedua, salah satu sumber hukum dalam penyelesaian perkara pada pengadilan di lingkungan Peradilan Agama adalah hukum yang bersumber dari hukum Islam yang kemudian sering didefinisikan sebagai fikih, yang sudah barang tentu rentan perbedaan. Untuk menjembatani perbedaan dan mewujudkan kepastian hukum, sekaligus untuk mewujudkan hukum Islam lahirlah Kompilasi Hukum Islam yang tema utamanya mempositifkan hukum Islam di Indonesia dan sebagai salah satu hukum terapan di lingkungan Peradilan Agama.

Ketiga, itsbat nikah atau dikenal juga dengan pengesahan nikah adalah merupakan penetapan pengadilan tentang sahnya suatu perkawinan. Dari beberapa landasan yuridis itsbat nikah sebagai kewenangan Peradilan Agama, Kompilasi Hukum Islam yang menjelaskan lebih rinci mengenai itsbat nikah termasuk alasan pengajuannya. Meskipun Kompilasi Hukum Islam (KHI) tidak termasuk dalam hirarki Peraturan Perundang-undangan. Namun demi untuk mengisi kekosongan hukum maka pasal-pasal yang mengatur mengenai itsbat nikah ini dinilai sebagai sebuah kebijakan yang sangat dibutuhkan oleh Peradilan Agama sebagai peradilan Islam di Indonesia.

\section{Daftar Rujukan}

Ahdabina, "Kompilasi Hukum Islam", bttp:// abdabina.staff.umm.ac.id//archives/240,

Diakses 2/7/2013.

Ali Daud, M., Pengembangan Hukum Material Peradilan Agama, Jurnal Mimbar Hukum: Aktualisasi Hukum Islam Nomor 17 Tahun V (Nov - Des 1994), Jakarta: AlHikmah dan Direktorat Pembinaan Badan Peradilan Agama Islam, 1994

Djalil A. Basiq, SH, MH, Peradilan Agama di

Indonesia, Jakarta, Kencana, 2006.

Hamami Taufiq, Mengenal Lebih Dekat, Kedudukan dan Eksistensi Peradilan Agama Dalam Sistem Tata Hukum di Indonesia, Bandung, Alumni, 
Harahap Yahya, M, Informasi Materi Kompilasi Hukum Islam: "Mempositifkan Abstraksi Hukum Islam", dalam, Kompilasi Hukum Islam dan Peradilan Agama dalam Sistem Hukum Nasional, Jakarta, Logos, 1999

HarahapYahya M., Kedudukan Kewenangan dan Acara Peradilan Agama, Sinar Gafika, Jakarta, 2001.

Ichtijanto, "Pengembangan Teori Berlakunya Hukum Islam di Indonesia", dalam, Hukum Islam di Indonesia Perkembangan dan Pembentukan, Bandung: Rosdakarya, 1991

Joseph Schacht, An Introduction to Islamic Law, Oxford: University Press, 1964

Muchsin, Masa Depan Hukum Islam di Indonesia, Jakarta: STIH Iblam, 2004

Munawar,Said Agil Husin al-., Hukum Islam dan Pluralitas Sosial, Jakarta:Penamadani, 2000

Nasruddin Enas, Ikhwal Isbat Nikah, Artikel dalam Mimbar hukum no. 33 tahun, 1977, Al Hikmah dan Ditbinbapera, Jakarta.
Noor Masrum, Isbat Nikah Bagi Warga Negara Indonesia di Luar NegeriI, http://www.pamagelang.go.id/component/content/articl e/52/262.

Nuruddin Amir dan Azhari Akmal Tarigan, Hukum Perdata Islam di Indonesia, Jakarta: Kencana, 2004

Prihantini Farida, dkk, Hukum Islam Zakat dan Wakaf Teori dan Prakteknya di Indonesia, Jakarta: Papan Sinar Sinanti \& FHUI, 2005

Ash-Shiddiqy Muhammad Hasbi, Falsafah Hukum Islam, Jakarta: Bulan Bintang, 1993.

Sunny Ismail, "Tradisi dan Inovasi Keislaman di Indonesia dalam Bidang Hukum Islam", dalam, Hukum Islam dalam Tatanan Masyarakat Indonesia, CikHasan Bisri (ed), Jakarta: Logos Publishing, 1988

Syarifuddin Amir, "Pengertian dan Sumber Hukum Islam", dalam Falsafah Hukum Islam, Jakarta: Bumi Aksara, 1992 